\title{
血管内皮細胞の初期伸展に及ぼす ハニカムフィルム細孔径の影響†
}

\author{
山本貞明 ${ }^{* * * *} \cdot$ 田中 賢 ${ }^{* * * * * *}$ ・伊藤絵美子*** 森田有香* \\ 角南 寛 ${ }^{* * * *}$ - 居城邦治 ${ }^{* *, * * *}$ 一下村政嗣 ${ }^{* * * * * *}$ \\ *北海道大学創成科学共同研究機構 寀 001-0021 北海道札幌市北区北 21 条西 10 丁目 \\ **北海道大学電子科学研究所附属ナノテクノロジー研究センター —001-0021 北海道札幌市北区北 21 条西 10 丁目 \\ **独立行政法人科学技術振興機構戦略的創造研究推進事業 踏 332-0012 埼玉県川口市本町 4-1-8
}

（2007 年 3 月 28 日受付；2007 年 5 月 17 日掲載決定）

\section{The Influence of Pore Size of a Honeycomb Film on Early Spreading Process of Endothelial Cells}

\author{
Sadaaki Yамамото ${ }^{* * * *}$, Masaru TANAKA ${ }^{* * * * *}$, Emiko Iтo***, Yuka Morita*, \\ Hiroshi SunAmi, ${ }^{* * *}$, Kuniharu IJIRO ${ }^{* * * * *}$ and Masatsugu ShImOMURA ${ }^{* * * * *}$
}

*Creative Research Initiative "Sousei” Hokkaido University, N21W10 Kita-ku, Sapporo, Hokkaido 001-0021

**Nanotechnology Research Center, Research Institute for Electronic Science, Hokkaido University, N21W10 Kita-ku, Sapporo, Hokkaido 001-0021

${ }^{* * *}$ Core Research for Evolutional Science and Technology (CREST), Japan Science and Technology Agency (JST), 4-1-8 Honcho, Kawaguchi, Saitama 332-0012

(Received March 28, 2007 ; Accepted May 17, 2007)

\begin{abstract}
The mechanism that cells use to recognize micro-patterned topographies was clarified. First, 3D double-layer poly $(\varepsilon-$ caprolactone) scaffolds equipped with honeycomb-patterned micro-pores ("honeycomb films") were prepared. Then, porcine aortic endothelial cells (PAECs) were cultured on these scaffolds for 1-6 h in serum-free medium. Finally, their initial spreading process was investigated by using AFM and confocal laser scanning microscopy. The attachment and spreading of PAECs on honeycomb films having either 6-or 16- $\mu \mathrm{m}$ pore diameters resulted in voids within the cell cytoplasm, which correspond with the size and location of the honeycomb micropores. The number of cells with this unique morphology decreased with increasing culture time. This dependence of morphology on film pore size and culture time suggests a spreading process of PAECs in which the cells spread trying to sense suitable sites to adhere. Using thick filopodia, the cells spread along the rim of the film and produced pores by close contact between two spreading filopodia. Evidently, these pores became filled in during culture, presumably as the cells began to reorganize their cytoplasma.
\end{abstract}

KEYWORDS : atomic force microscopy, cell adhesion, cell spreading, surface topography, endothelial cell, tissue engineering

\section{1.は じめに}

ドナー不足と免疫拒絶の問題点を抱えた臓器移植に替

\footnotetext{
第 26 回表面科学講演大会（2006 年 11 月 6 日〜 11 月 9

日）にて発表

E-mail : syama@cris.hokudai.ac.jp
}

わる新しい治療法として，再生医療が注目されている。 その実現を目指し, 細胞の分化や増殖を制御して, 生体 組織を作る組織工学が活発に研究されている ${ }^{11}$ 。組織工 学では, 足場材料（細胞が接着して増殖, 分化し組織を 形成する細胞培養基材）が, 用いる細胞と増殖や分化な どを制御する液性因子と並んで重要な開発課題となって 
いる。細胞が材料表面を認識するという最初の報告 ${ }^{2}$ 以 来, 細胞の増殖, 分化あるいは機能発現と足場材料表面 との相関性は組織工学に扔ける重要な課題として研究さ れてきた。足場材料表面の化学的性質, 電荷, 硬さ, 形 態などが細胞の接着, 形態, 伸展, 移動, 増殖, 分化な どの細胞挙動に与える影響について議論されている。最 近, リソグラフィーなどの表面微細構造作製技術の長足 な進歩によりマイクロサイズ, あるいはナノサイズの表 面規則構造を持った足場材料の作製が可能になり, それ らを足場材料に用いた培養を行って, 表面形態が細胞挙 動にどのような影響を与えるかを明らかにする研究が行 われている ${ }^{3 \sim 11}$ 。我々は溶媒蒸発時の結露で生じた水滴 の自己組織化現象を利用してミクロンサイズの細孔が蜂 巣状に規則正しく並んだフィルム（以下ハニカムフィル ムと呼ぶ）を製造する方法を開発した ${ }^{12,13)}$ 。本製膜方法 は, 化学組成を変えることなく (1) 数百 $\mathrm{nm}$ から数十 $\mu \mathrm{m}$ の範囲で細孔径を均一精密に制御できることや，(2作製 したフィルムを延伸することによって, 細孔形状を容易

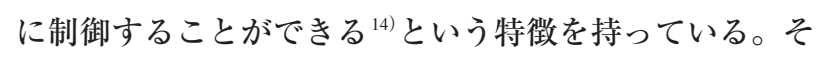
のフィルムを細胞培養の足場として心筋細胞, 肝実質細 胞, 神経幹細胞の培養を行って, ハニカムフィルムがそ の細孔サイズや形状によって細胞の形態, 増殖, 分化あ るいは機能を制御しうる足場材料としてのポテンシャル を持つことを明らかにしてきた ${ }^{1418)}$ 。最近，八ニカム フィルムの細孔サイズによって血管内皮細胞の進展, 接 着点, 増殖㧍よびタンパク質産生能が大きく影響を受け ることを見出した ${ }^{18)}$ 。表面形態によって細胞挙動がどの ように影響を受けるのか, それはいかなる機構によるも のなのかを明らかにすることは, 優れた足場材料の開発 にとって重要な研究課題であり, 活発な研究が行われて いるものの，まだ十分とは言えず，機構についても不明 な点が多い。

培養液中の血清には様々のタンパク質が含まれてい て, 細胞は血清から足場材料表面に吸着した夕ンパク質 を介して足場材料表面に接着する。このような細胞接着 に関わるタンパク質は細胞接着性タンパク質といわれ, フィブロネクチン $(\mathrm{Fn})$ はその代表的なタンパク質で ある ${ }^{19,20)}$ 。そこで前報では八ニカムフィルムによる細胞 挙動の制御機構の解明を目的として, ハニカムフィルム が細胞接着性タンパク質として代表的な Fn の吸着に及 ぼす影響を調べた。そして Fn の吸着サイトと血管内皮 細胞の増殖, 分化やタンパク質産生能に大きく関係する 接着点形態とシグナル伝達タンパク質の活性化との相関 性を検討し, ハニカムフィルムにより Fn の吸着サイト が支配され, その吸着サイトによって細胞の接着点構造 （密度, 周期性）が決まり, 細胞の増殖, 分化, 機能が
制御されている可能性を見出した ${ }^{21,22) 。 し か し な か ゙ ら, ~}$ この研究においては, 細胞接着性タンパク質が存在する ため, 細胞が八ニカムフィルム表面形状をどのように認 識して, それが細胞挙動にどう影響を及ぼすのかという 本質的に重要な問題については不明であった。

本研究では, ハニカムフィルムの規則構造を細胞がど のように認識しているのかを調べることを目的として, $3 \mu \mathrm{m}, 6 \mu \mathrm{m}$ および $16 \mu \mathrm{m}$ の細孔径を持つハニカムフィ ルムを培養基板として細胞接着性タンパク質を除いた培 養条件（無血清培地）でブタ大動脈由来血管内皮細胞の 培養を行い, 細胞の増殖が始まらない細胞サイクル初期 にある細胞の伸展挙動を AFM による細胞形態の観察と 細胞骨格タンパク質であるアクチンおよび細胞膜を染色 した細胞の共焦点レーザ顕微鏡観察によって調べた。

\section{2. 実}

験

\section{フィルム作製}

フィルム作製には Poly（ع-caprolactone）（PCL，分子 量 70000-100000, Wako Japan）および dodecylamide と $\omega$-carboxyhexylacrylamide からなる両親媒性ポリマー （Cap）を用いた（Fig. 1)。Capは既報に従って合成し た ${ }^{23)}$ 。PCL と両親媒性ポリマー（CAP）の混合溶液（ク ロロホルム溶媒 (Wako), PCL : CAP = 10:1（wt\%)） をガラス基板上にキャストし高湿度下（相対湿度 80〜 90\%）で溶媒を蒸発させ，細孔径 3，6，および $16 \mu \mathrm{m}$ の ハニカムフィルムを作製した ${ }^{12,13)}$ 。同じ溶液を低湿度下 でスピンキャストし，比較のための細孔のない平膜を作 製した。

\section{AFM, CLSM, SEM 測定}

フィルム表面の粗さおよび細胞形状は AFM（Digital Instruments 社（Santa Barbara, CA）製 Nanoscope III a ）を 用いて行った。用いた探針は共振周波数〜 $300 \mathrm{kHz}$ ，バ ネ定数 $14 \mathrm{~N} / \mathrm{m}$ の Si マイクロカンチレバーである。走 查速度を $0.1 \sim 0.2 \mathrm{~Hz}$ として大気中, タッピングモード で測定した。平膜および八ニカムフィルム幹表面の平均 粗さ $(\mathrm{Ra} / \mathrm{nm})$ は，それぞれ 2 枚のフィルムの表面（ハ

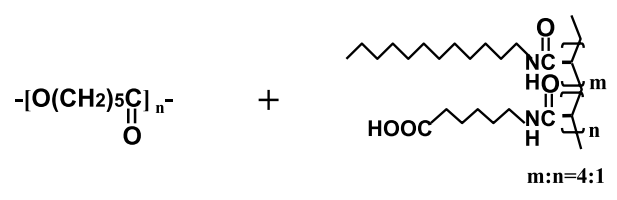

Poly ( $\varepsilon$-caproractone) (PCL) Amphiphilic polymer(CAP)

PCL:CAP=10:1(wt\%)

Fig. 1. Chemical structure of the polymers used in honeycomb films. 
ニカムフィルムは幹上）の任意に選んだ 6 か所での $1 \mu \mathrm{m}$ 角での測定值を平均することにより求めた。共焦 点レーザー顕微鏡観察は Olympus 社製 FLUOVIEW FV300を用いて行った。SEM 観察はHitachi S-3500N SEM を用い, 加速電圧を $15 \mathrm{kV}$ で行った。

細胞培養, アクチンおよび細胞膜の蛍光染色

ブタ大動脈血管内皮細胞 (PAEC, CSC Certificate TM DAINIPPON PHARMACEUTICAL CO., LTD., Japan) を $100 \mathrm{unit} / \mathrm{ml}$ ペニシリン $/ 100 \mu \mathrm{g} / \mathrm{ml}$ ストレプトマイシン （GIBCO）を含む無血清培地（Dulbecco’s Modified Eagle’s Medium, Sigma, Munich) に分散させた。滅菌水
で洗浄したフィルムに継代 6-8 の PAECを播種密度 $1.5 \times 10^{4}$ cells $/ \mathrm{cm}^{2}$ で播種し $37^{\circ} \mathrm{C} ， 5 \% \mathrm{CO}_{2}$ 雲囲気で培養 した。培養 1，3，6および 72 時間後，フィルムを室温 で 10\% ホルマリン（Wako, Japan）に 10 分浸漬, 次いで PBS 溶液で洗浄した後, アクチン（Alexa Fluor 488 phalloidin または Rhodamine phalloidin, Molecular Probes, Inc. Eugene, OR）と核（DAPI, DOJINDO Japan）を染色した。 細胞面積および周囲長, 接着数の測定

画像解析ソフト Image-Pro PLUS (Media Cybernetics, Inc. MD）を用いてアクチン染色像から, 細胞面積と周 囲長を，また核染色像から細胞接着数を求めた。測定範

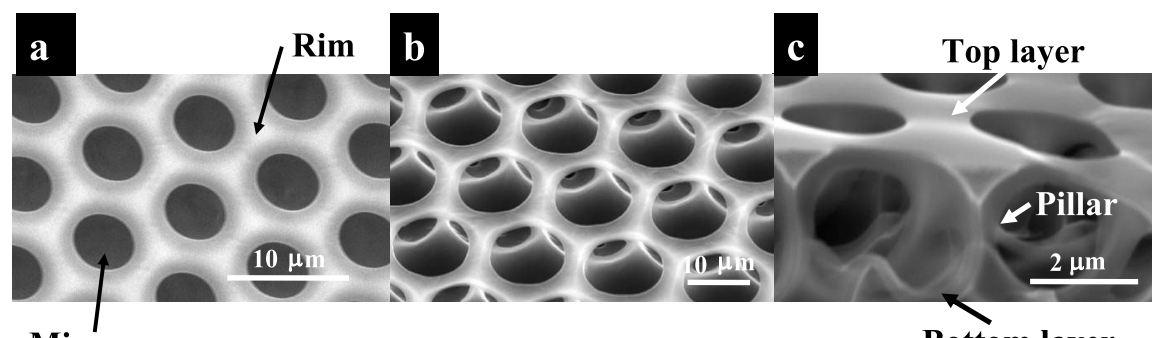

Micropore

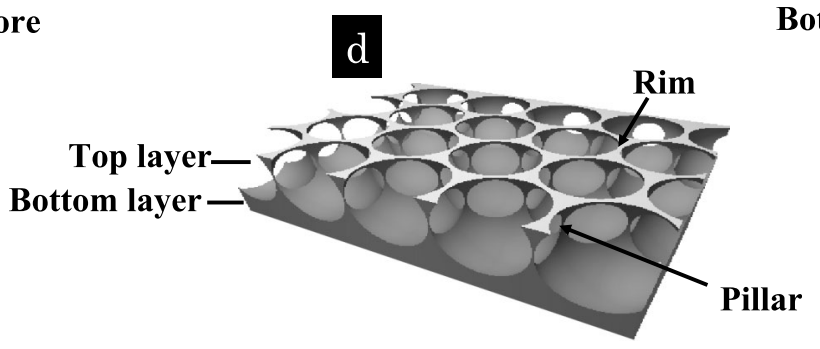

Fig. 2. SEM images of a honeycomb-patterned film. (a) top view, (b) tilted view, (c) side view, and (d) schematic of double-layered honeycomb film. Top layer with honeycomb-patterned pores is connected by pillars to bottom layer.
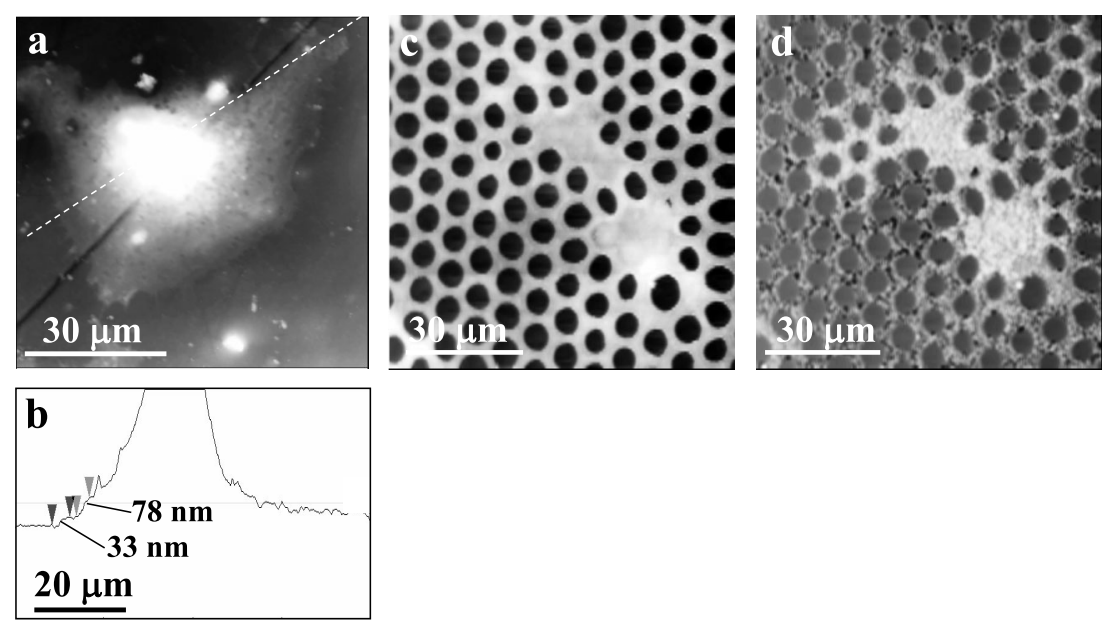

Fig. 4. AFM images showing the morphology of PAECs cultured $1 \mathrm{~h}$ on a honeycomb and flat film. a) topographic image on a flat film, b) crosssectional profile along the dotted line in a). c) topographic and d) phase images on a honeycomb film with a pore diameter of $6 \mu \mathrm{m}$. The images were obtained by using tapping mode in air. 
囲は約 $160000 \mu \mathrm{m}^{2}$ とした。

\section{3. 結果}

\section{ハニカムフィルムの構造}

Fig. 2 は PCL ハニカムフィルムの構造を示す SEM 像 である。フィルムを真上から観ると微細な孔が六方細密 に規則的に配列していることがわかる（Fig. 2a）。断面 観察図（Fig. 2c）はハニカムフィルムが 2 枚の薄膜が六

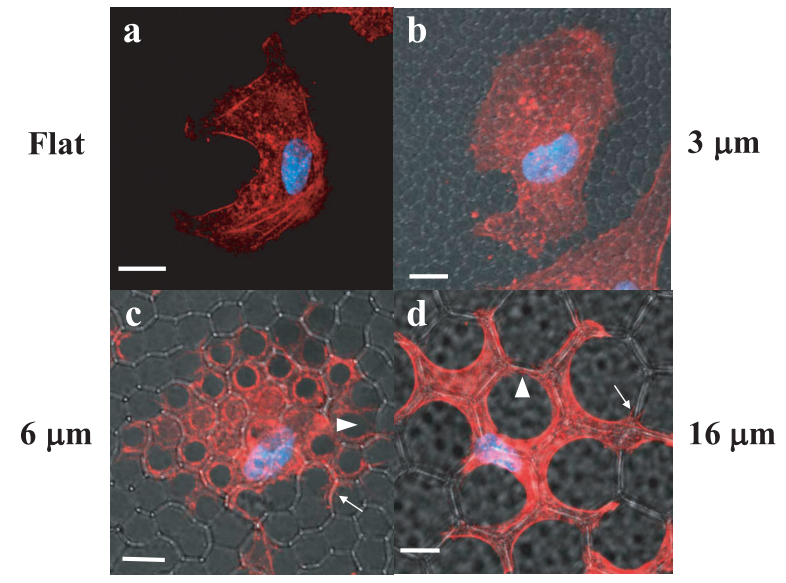

Fig. 3. CLSM images of PAECs immunofluoresently stained for actin after $3 \mathrm{~h}$ culture on a) flat film, and honeycomb films with a pore diameter of b) 3 , c) 6 , and d) $16 \mu \mathrm{m}$, respectively. The images superimposed on the differential interference microscope images of honeycomb films show the dependence of spreading morphology on the pore size. Arrows in c) and d) indicate thin filopodia interacting with the surface of honeycomb rim. Arrow heads in c) and d) show thin filopodia interacting each other. ber : 10 $\mu \mathrm{m}$.
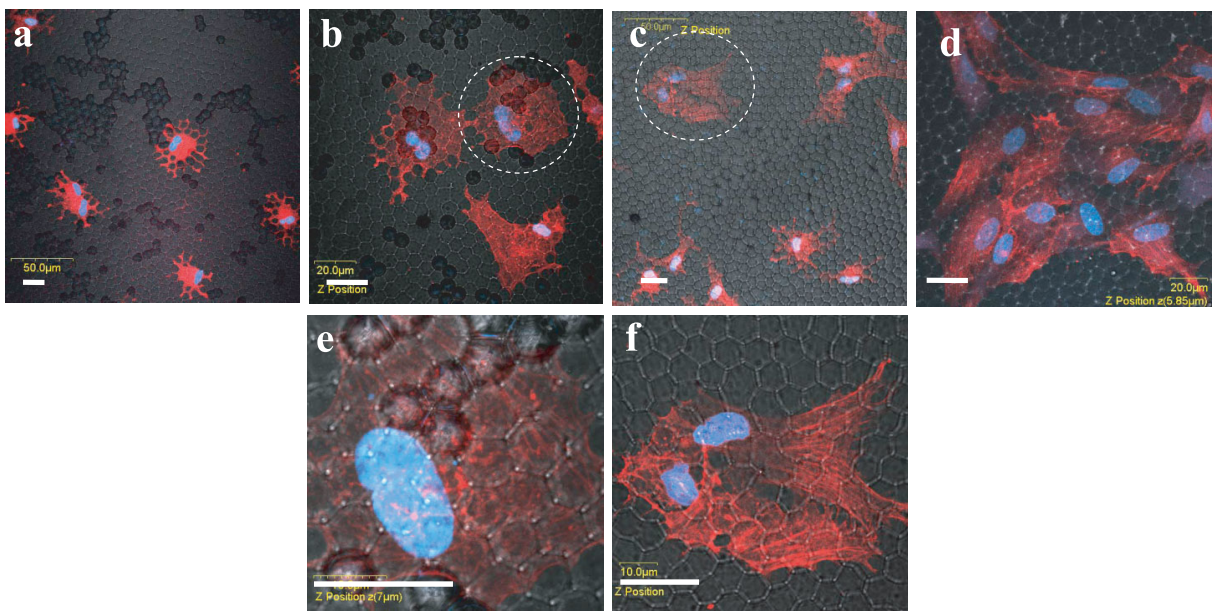

角形の頂点にあるピラーでつながった二層構造をしてい ることを示す。このような規則的三次元構造を細胞がど のように認識するのかをみるために, 次に細胞の伸展初 期形態を調べた。

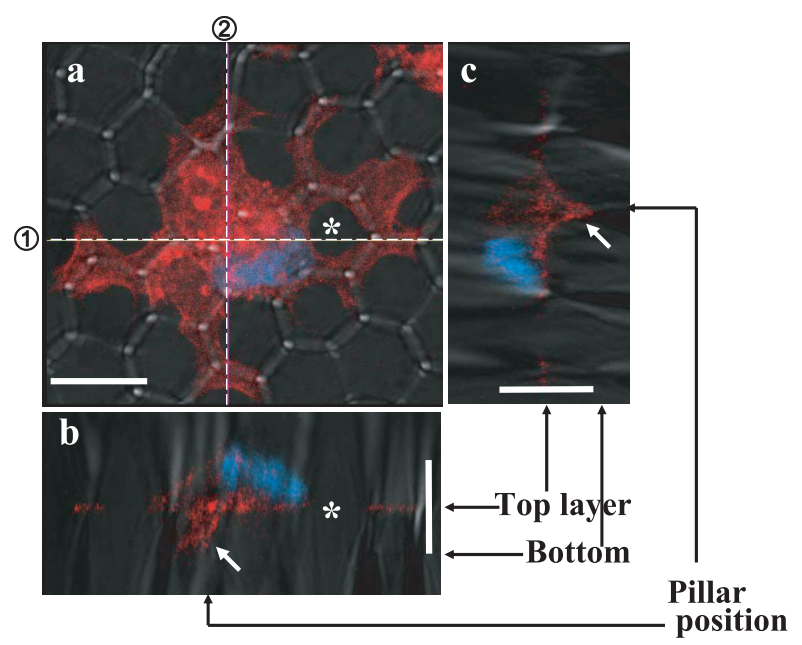

Fig. 5. CLSM depth image of a PAEC immunofluorescencely stained for actin after $1 \mathrm{~h}$ culture. a) CLSM image superimposed on a differential interference microscope image of a honeycomb film, b) depth image across the dashed line of (1) in a) that shows no fluorescence from actin at the honeycomb pore, demonstrating the voids within the cell cytoplasm, which correspond with the size and location of the honeycomb pore (indicated by ${ }^{*}$ in a) and b)). c) depth image across the dashed line of (2) in a). The depth images reveal that the cells migrated into the honeycomb pores along the honeycomb pillars (indicated by an arrow in b) and c). ber : $10 \mu \mathrm{m}$.

Fig. 6. CLSM images of PAECs immunofluoresently stained for actin (red) on honeycomb films with a pore diameter of $6 \mu \mathrm{m}$ showing the dependence of the spreading morphology of PAECs on culture time. Culture time : a) 1 h, b) 3 h. c) 6 h, and d) 72 h. e) close-up image of encircled region in b) f) close-up image of encircled region in c). Blue is nuclear. Bar : $20 \mu \mathrm{m}$. 


\section{細胞伸展形態}

Fig. 3 は異なる細孔径を持つハニカムフィルム上で, 3 時間培養を行った後, 細胞骨格タンパク質であるアク チンを蛍光染色した PAEC の CLSM 像を示す。CLSM 像はハニカムフィルムの細孔位置と細胞の相対関係がわ かるようにハニカムフィルムの微分干渉像を重ね合わせ てある。Fig. 3 は細胞の伸展形態がハニカムの細孔径に よって大きく異なることを明瞭に示している。細孔径 3 $\mu \mathrm{m}$ のハニカム上の細胞の周囲には突起状の仮足が見ら れた（Fig. 3b）。それらの仮足は細孔を飛び越えて伸展 していた。この形態は平膜上の形態（Fig. 3a）と類似し ていた。一方, 細孔径 6 および $16 \mu \mathrm{m}$ のハニカムフィ ルム上では, ハニカムフィルム細孔の位置にその孔径と 等しい孔を持った細胞が数多く観察された（Fig. 3c, d)。これらの形状は平膜および細孔径 $3 \mu \mathrm{m}$ のハニカム フィルム上の形態とは全く異なる形態であって, 今回, 初めて見出された形状である。幹上を伸展する太い仮足 先端には, 平膜あるいは細孔径 $3 \mu \mathrm{m}$ のハニカムフィル 厶上で見られた突起状の仮足が見られ（Fig. 3c，d 中， 矢印で示した)，伸展先を探索している様子がうかがえ る。細胞膜同士の接着の初期を示すと思われる隣接する 突起同士が接触している瞬間もとらえられている（Fig. $3 \mathrm{c}$ 中三角印で示した)。Fig. $4 \mathrm{a}$ は平膜上の PAECの AFM 像を示す。細胞の周囲には, CLSM で観察された と同様の突起状の仮足が観察された。断面解析により細 胞周囲の厚さは数十 $\mathrm{nm}$ と非常に薄いことがわかった (Fig. 4b)。ハニカムフィルム上の PAEC の AFM による 形状観察では細胞全体の形態がわからないが (Fig. 4c), 位相像では，CLSM 像と類似の孔を持った形態が観察さ れた（Fig. 4d）。AFM により求めた平膜およびハニカム フィルム幹の表面粗さ（Ra）はそれぞれ 12 および 42 $\mathrm{nm}$ であった。形状像でハニカムフィルム上の細胞の全 体がみられないのは，ハニカムフィルムの幹表面の凹凸 が大きく形状像では数十 $\mathrm{nm}$ の非常に薄い細胞の伸展部 分は分解されにくいためと考えられる。Fig. 5 は培養 1 時間後, アクチンを蛍光染色した PAEC の CLSM 断面 観察像である。ハニカムフィルムのピラーに沿って細胞 がフィルム内部に伸展していることを示している（Fig. $5 \mathrm{~b}$ および $\mathrm{c}$ 中，矢印で示した)。また，フィルム細孔に あたる位置（Fig. 5a および b の*印で示す）では，フ イルム top および bottom いずれの表面でも染色したア クチンからの蛍光は検出されなかった。このことはハニ カム細孔位置で細胞に孔が開いていることを示してい る。

\section{細胞伸展形態の培養時間依存性}

本研究で初めて見出された血管内皮細胞の伸展形態の
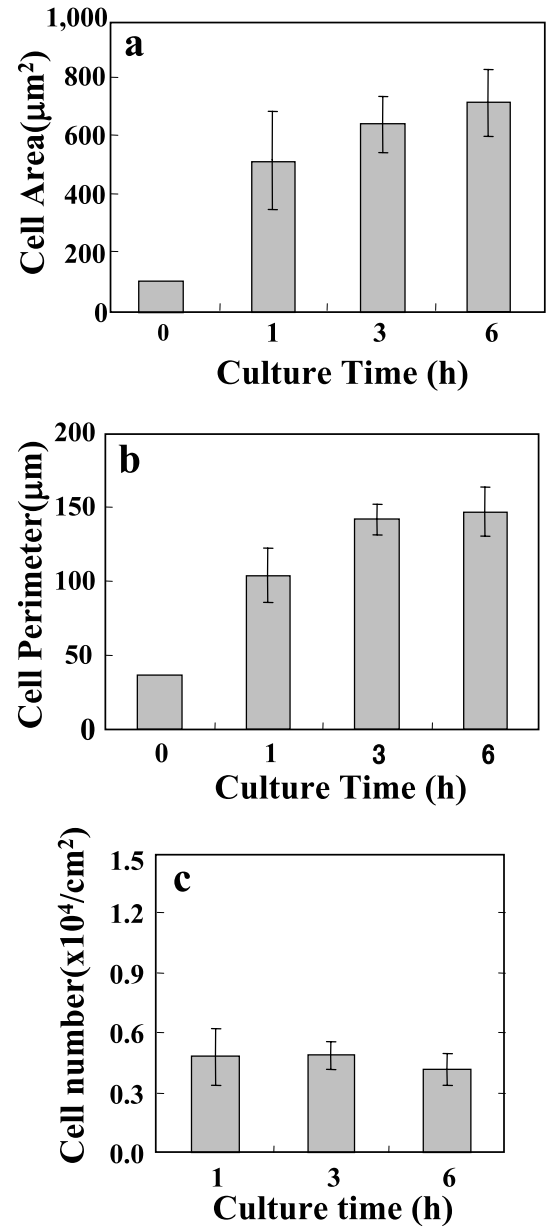

Fig. 7. The culture time dependence of a) cell area, b) cell perimeter, and c) cell number on culture time. The honeycomb micorpore diameter is $6 \mu \mathrm{m}$.

形成プロセスを明らかにするために，伸展形態の培養時 間依存性を調べた。Fig. 6 は培養 1 時間から 72 時間ま での間に観察された典型的な血管内皮細胞の伸展形態を 示す。培養初期 1 時間では，孔の開いた細胞が多く観察 された (Fig. 6a)。培養 3 時間および 6 時間と培養時間 が長くなるに従って，孔の開いた細胞数が減って，孔の まったくない細胞数が増加した（Fig. 6b, c 中波線丸で 囲った細胞)。孔のない細胞を拡大して観察すると, 数 多くの線状のアクチン繊維が細胞内に走っていることが わかった（Fig. 6d，e）。さらに 72 時間の培養では，孔 の開いた細胞はなく, 線状にアクチン繊維が発達した細 胞のみが観察された（Fig. 6f）。

伸展細胞の面積, 周囲長および接着率の培養時間依 存性

Fig. 7a， b は各培養時間における伸展速度の指標とな る全細胞の伸展面積と周囲長を示す。伸展面積と周囲長 のいずれも播種後 1 時間で増加し, その後, 3 時間から 6 時間では大きな増加は示さず，ほぼ一定となることが 
わかった。細胞の接着率は培養 1 時間から 6 時間の間で ほぼ一定であることがわかった（Fig. 7c）。したがって， 観察された面積と周囲長は, はじめに播種された全細胞 の培養 1,3 および 6 時間での伸展面積を表していると 考えられる。

\section{4. 考察}

Fig. 3 のアクチンを蛍光染色した細胞の CLSM 像と Fig. 4d の AFM 位相像は細胞に孔が開いていることを示 している。Fig. 2 の SEM 像が示すように, フィルムは 3 次元構造を持つので, フィルム細孔の位置で, 細胞が内 部に入り込み bottom 層を伸展しているために top 層の CLSM 観察では蛍光が検出できず，また AFM 探針が細 孔下層を検知できないために孔が開いているように見え ている可能性が考えられる。しかしながら Fig. 5 に示す ようにCLSM による断面観察によっても, 細孔の bottom 層位置で蛍光が観察されないので, ハニカムフィル ムの細孔位置に一致するところには細胞質がなく, 実際 に細胞には孔があいているといえる。ナノメートルサイ ズの表面形状をもつポリマー表面での血管内皮細胞の伸 展形態が調べられていて, その形態は $3 \mu \mathrm{m}$ の細孔径を 持つハニカムフィルム上と類似している ${ }^{5)}$ 。このような 孔の開いた血管内皮細胞の形態は本研究で初めて見出さ れたものである。細孔径 3 ミクロンのハニカムフィルム 上の細胞形態は平膜上と同じく（Fig. 3a, b), 細孔径が 6 および $16 \mu \mathrm{m}$ のハニカムフィルム上の細胞形態は平膜 上とは全く異なっている（Fig. 3c, d）ということは, 細胞が $3 \mu \mathrm{m}$ と $6 \mu \mathrm{m}$ 以上の細孔の大きさを感知・識別 していることを示している。

培養時間が長くなるにつれて孔の開いた細胞の割合は 減少し, 変わって, 孔を持たず線状のアクチン緎維が発 達した細胞が見られるようになる（Fig. 6e, f）。孔が培 養時間とともに, どのようになるのかをみるために, 極
端に培養時間を長くすると (培養 72 時間), 孔の開いた 細胞は見られず, 孔を持たず線状のアクチン繊維が発達 した細胞のみが観察される（Fig. 6d）。孔を持った細胞 の割合が低くなるのは, 孔の開いた細胞が選択的にアポ トーシス等の理由によって基板から外れてしまった可能 性が考えられるが, 培養 1 時間から 6 時間にわたってハ ニカムフィルム上の細胞数が一定であるということから (Fig. 7c), この可能性は否定され, 細胞は培養経過にと もなって, 孔を埋めているといえる。さらに, 伸展する 細胞の面積と周囲長が培養 1 時間までは増加し, それ以 降，6時間では大きな増加が見られないことから（Fig. $7 \mathrm{a}, \mathrm{b})$, 培養 1 時間以降では, 細胞は伸展を止め, 孔の 修復とアクチン骨格の形成を開始しているものと考えら れる。現在のところ, 細胞が孔をどのようにして埋めて 行くのかは不明であるが, 一つの細胞が持つ孔のサイズ はその過程を考える手がかりを提示している。各々の孔 が, ランダムに埋められていくものであるとすれば, 各 培養時間で細胞形態を観察すると, 一個の細胞には径の 異なった孔が観察されるべきである。しかしながら Fig. 3 や Fig. 6 に示すように, 培養 3,6 時間での複数の孔 が開いた細胞の孔径は均一であって, ハニカムフィルム の細孔径に等しい。また, 孔のない細胞では, 孔が見ら れない（Fig. 6)。このことから, 各孔はランダムに埋め られていくのではなく, 短い時間（今回の実験では培養 1 時間と 3 時間の間, つまり最大で 2 時間。実際はそれ よりも早いことが考えられる) の間にそろって（協奏的 に）埋められていると考えられる。細胞内に孔を埋める 作業開始の何らかのシグナルが生じ, 細胞質の細胞内移 動が生じて，そろって孔が埋められているのではないか と考えられる。細胞が何をもって伸展を止め, 孔の修復 とアクチン纎維の形成を開始するかは非常に興味ある問 題であるが, その解明は今後の課題である。

伸展形態の細孔径依存性と培養時間依存性から, ハニ

\section{Culture time}
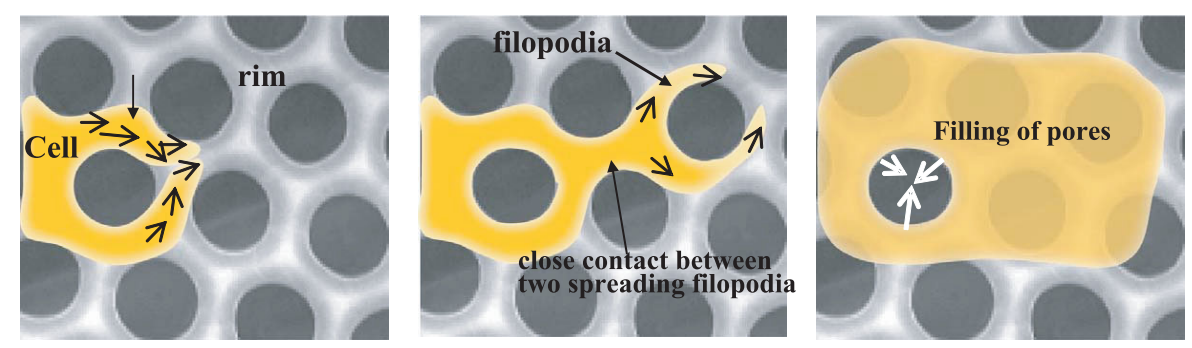

Fig. 8. (color online). Schematic presentation of proposed spreading process of PAECs in which the cells spread, trying to sense suitable sites on which to adhere. Using thick filopodia, the cells spread along the rim of the film and produced pores by close contact between two spreading filopodia. Evidently, these pores became filled in during culture, presumably as the cells began to reorganize their cytoplasma. 
カムフィルム上の血管内皮細胞の伸展プロセスは次のよ うに考えられる（Fig. 8)：細胞は $3 \mu \mathrm{m}$ と $6 \mu \mathrm{m}$ のサイズ の大きさの違いを識別し, $6 \mu \mathrm{m}$ 以上では細孔を越える ことなく, 細胞は幹に沿って仮足を伸ばす。伸展途中に

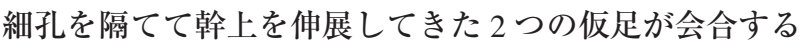
ことで孔形状を形成し, さらに伸展を続ける。ある程度 伸展した, 培養開始後 3〜6 時間で伸展がとまり, 細胞 質の移動によって孔が埋められる。

\section{5. ま め}

固体表面形状が細胞挙動に及ぼす影響の解明は培養基 材の開発にとって重要な課題である。本研究では, その 解明を目的として, 血管内皮細胞がハニカムフィルムの 規則的三次元構造をどのように認識するかを調べた。そ の結果, 細胞はハニカムフィルムの細孔の大きさを識別 した特異的な進展を行っていることがはじめて明らかに なった。 $3 \mu \mathrm{m}$ の細孔径を持つハニカムフィルム上では, 平膜上と同様の伸展形態を示すのに対し，6および 16 $\mu \mathrm{m}$ の細孔径を持つハニカムフィルム上では, ハニカム フィルムの細孔位置に細孔サイズと等しい大きさの孔が 開いた細胞形態が観察された。さらに, その形態は培養 時間が長くなるに従って消失することが明らかになっ た。この特異的形態の形成に関連して, どのようにして 細胞が $3 \mu \mathrm{m}$ と $6 \mu \mathrm{m}$ の孔を識別して伸展方法を決めて いるのか？会合した位置で細胞膜は単に接触している のか？あるいは, それより強い膜間の相互作用が引き 起こされているのか？など興味ある課題が明らかにな った。また, 孔の消失は協奏的に起きていることが考え られ, 細胞のより梁い理解への手がかりを提示してい る。今回明らかになった現象には基板の表面形状と構造 が大きく関わっていることが予想され, 今後, 表面科学 的手法によるアプローチにより, 更なる解明にせまる予 定である。本研究結果は, 細胞培養基材の開発にとって 表面科学が果たす役割の大きさを示している。

\section{謝辞}

本研究は, 文部科学省科学技術振興調整費戦略的研究 拠点育成プログラム「北大 R \& BP 構想」と JST 戦略的 創造研究推進事業医療に向けた自己組織化等の分子配列 制御による機能性材料・システムの創製領域「高分子の 階層的自己組織化による再生医療用ナノ構造材料の創 製」の支援を受け, 創成科学共同研究機構において実施 された。

\section{文献}

1) R. Langer and J.P. Vacanti : Science 260, 920 (1993).
2) A. Carrel and M. Burrows : J. Exp. Med. 13, 571 (1911).

3) E.T. den Braber, J.E. de Ruijter, L.A. Grinsel, A.F. von Recum and J.A. Jansen : J.A. j. Biomed Mater. Res. 40, 291 (1998).

4) R.G. Flemming, C.J. Murphy, G.A. Abrams, S.L. Goodman and P.F. Nealey : Biomaterials 20, 573 (1999)

5) M.J. Dulby, M.O. Riehle, H. Johnstone, S. Affrossman and A.S.G. Curtis : Biomaterials 23, 2945 (2002).

6) A.I. Teixeira, G.A. Abrams, P.J. Bertics, C.L. Murphy and P.F. Nealey : J. Cell Sci. 116, 1881 (2003).

7) D. Motlagh, T.J. Hartman, T.A. Desai and B. Russell : J. Biomed. Mater. Res. 67A, 148 (2003).

8) M.J. Dalby, S. Childs, M.O. Riehle, H.J.H. Johnstone, S. Affrossman and A.S.G. Curtis : Biomaterials 24, 927 (2003).

9) M. Arnold, A.E. Cavalcanti-Adam, R. Glass, J. Blümmel, W. Eck, M. Kantlehner, H. Kessler and J.P. Spatz: ChemPhysChem. 5, 383 (2004).

10) C.C. Berry, M.J. Dalby, D. McCloy and S. Affrossman : Biomaterials 26, 4985 (2005).

11) M.J. Dalby, M.J. P Biggs, N. Gadegaard, G. Kalna, C.D.W. Wilkinson and A.S.G. Curtis : J. Cl. Biochem. 100, 326 (2007).

12) N. Maruyama, T. Koito, J. Nishida, T. Sawadaishi, X. Gieren, K. Ijiro, O. Karthaus and M. Shimomura: Thin Solid Film 854, 327 (1998).

13) M. Tanaka, M. Takebayashi, M. Miyama, J. Nishida and M. Schimomura : Bio-Med. Mater. Eng. 14, 439 (2004).

14) T. Nishikawa, M. Nonomura, K. Arai, J. Hayashi, T. Sawadaishi, Y. Nishiura, M. Hara and M. Shimomura : Langmuir 19, 6193 (2003).

15) K. Sato, K. Hasebe, M. Tanaka, M. Takebayashi, M. Nischikawa, M. Schimomura, T. Kawai, M. Matsushita and S. Todo : Int. J. Nanosci. 1, 689 (2002).

16) M. Tanaka, K, Nishikawa, H. Okubo, H. Kamachi, T. Kawai, M. Matsushita, S. Todo and M. Schimomura : M. Colloids Surf. A. 464, 284 (2006).

17) A. Tsuruma, M. Tanaka, N. Fukushima and M. Shimomura : e-J. Surf. Sci. Nanotech. 3, 159 (2005).

18) M. Tanaka, A. Takayama, E. Iti, H. Sunami, S. Yamamoto and M. Shimomura : J. Nanosci. Nanotech. 7, 763 (2007).

19) R.O. Hynes : "Fibronectin” (Springer, New York, 1990) p. 546.

20) 藤本大三郎編 : “細胞外マトリックスのバイオサイ エンスとバイオテクノロジー” (アイシーピー) p. 111.

21) S. Yamamoto, M. Tanaka, H. Sunami, K. Arai, A. Takayama, S. Yamashita and M. Shimomura: J. Surf. Sci. Soc. Jp. 27, 502 (2006).

22) S. Yamamoto, M. Tanaka, H. Sunami, K. Arai, A. Takayama, S. Yamashita, Y. Morita and M. Shimomura : Surf. Sci. 600, 3785 (2006).

23) S. Nishimura and K. Yamada : J. Am. Chem. Soc. 119, 10555 (1997). 